Copyright (c) 2006 Associação Brasileira de Pesquisadores em Jornalismo / SBP Jor

\section{THE WOMEN OF ISLAM}

The role of journalistic photography in the (re)production of character-type ${ }^{1}$

\author{
KATI E. CAETANO \\ Universidade Tuiuti do Paraná, Brazil
}

ABSTRACT

the idea, as a starting point, that some images incite one to acts of contemplation, mediated by ambivalent meanings and sensations, this study proposes an interpretation of the photographs of Islamic women in the Brazilian press. Their condition as a figure present in the media is a concern, above all recurring in the contemporariness, in the places usually occupied by political content involving the conflicts between the East and West, and therefore on the whole and in the economy of the illustrative visual information of the first page news or the World section. Thus, the Muslim woman's image in several articles metaphorically appears as a source of evocation of a culture characterized by restrictions of behavior and values that seem strange to us, apparently personified in the solitary and anonymous figure or in the ordered crowd of women covered by the black veil of furtive glances.

KEY-WORDS

Picture; journalism; female representation; visual communication; documental image

\title{
1 - INTRODUCTION
}

This article examines some recurring photographs of Islamic women in the Brazilian press, investigating the role that they undertake as documental images of sociopolitical matters. Registered in private cultural reference systems, these figures not only emerge from distant worlds to our eyes, but they also leave us immersed in a system of interpretative associations, whose parameters are regulated by distance and strangeness.

Mostly originating from international agencies, like Reuters, Associated Press and France Presse, the images are posted with illustrative titles in reports or news programs about the conflicts in or about the Middle East, generating astonishment because of 
the thematic displacement they seem to have in relation to the verbal displacement, since the female question is not even suggested in the issue. At the first reading, we fathom the impression of a certain negligence with the documental foundation that such images can ensure, having in mind, above all, the fact already identified by Jacques Wainberg that the media, impelled by the little interest shown by the Brazilian public with respect to world news, "tend to simply replicate the news of the international agencies, investing little in the national production of this content, even in situations of extreme crisis" (WAINBERG,2005: 136-138).

From the beginning it must be elucidated that this is not a study on the female question in Islam. There is no intention of considering the female Islamist, in relation to her conventional opposite, the male Islamist, other than as an existing figure in a realm usually pervaded with political content involving the conflict between East and West, and therefore as a whole and in the economics of the illustrative visual information of the headline news or World section, as well as in editions organized for publication of all material obtained in the reports. One can ask, therefore, to what extent is the image of this woman useful for the purposes of a political discussion; to what extent does her condition become questioned in the setting outlined by the general information of the page and what is the facet constructed to show and signify the female representation in this specific case?

Contingencies of several types circumscribe the discussion, because of the fact that the reproduction of female Islamic images is strongly challenged by the standards of reproduction of women's images in the West. Two of these contingencies are immediately fundamental: 1) Women of the Islamic world are not supposed to allow themselves to be seen, and therefore should not pose for pictures; consequently they should not face the photographer nor, through him, the reader/viewer of the image, while Western women root themselves, as well as their society in general, in a kind of cult of visibility, especially that provided by the media; 2) the divergences on several levels seem to reflect, in condensed form, an aspect of the cultural norm of dressing and covering oneself almost completely, which leads to a game of appraising examinations from both sides (the West and the Islamic East), obviously structured upon absolutely dissonant ideological values. As with every type of stereotypical action, this differentiated practice breeds manifestations of judgment by one side of the other immediately grounded upon a negative axiomatic theory of the inconvenience of the other side's uses and habits. 
This game of reciprocal examinations is no doubt infected with cultural values, which leads to surrounding the perceptive act regarding a feminine image of both sides with models of apprehension and negative or, at least, different moral standards. In the eyes of the Muslim society, the Western woman's exhibition is equally or more discussed than the Islamic woman's concealment by Westerners. However an inherent problem arises that should be immediately discussed: firstly, talking about the confrontation of two civilizations, although this has been recurring among several specialists in contemporariness, is to be exposed to a limiting reflection of the complexity of the aspects that permeate modern societies, especially the ideological digressions present in the heart of Arab societies; in the same way, a reference to the Islamic or Western woman spawns much additional mortification because of the non-differentiation attributed to a polychromatic existence and the life experience of women in the entire world, who, before being considered women, are also human beings, and, as such, subjected to an endless series of problems, longings and emotions inherent in this condition. This dualism is therefore employed to contextualize the discussion about the reproduction of genres in the panorama, conscious that it is just a slice of an immensity of other discussions that would sustain what is intended to be accomplished.

Several works were developed on the subject of the Western woman's representation in the media, grouped in different thematic roles as the housewife, the seductress, the sensualist, the woman of character, the executive, the intellectual, the shy, the bold, the impulsive, the mundane, etc. For the most part, in the rare moments in which a woman is portrayed in her human totality, susceptible to ambiguities, ambivalence, and conditioned by socioeconomic structures (in the arts and in literature, for instance), such representations select or emphasize one of the narrative roles, from which is derived the figurativeness of a specific model of woman, with her manner of acting, looking, gesticulating or positioning, dressing, walking and adorning herself. That is the Western way of seeing Westerners, in their various manifestations and modalities originating from the regional, national and transnational stereotypes. It is not possible to delineate some of the Eastern views on Westerners (or the West in general) ${ }^{2}$ here, and not even some of the Eastern views (the Islamic East, focus of this analysis) regarding their own wives. The intention here is to examine the forms of representation, meaning effects and the ideological implications resulting from the (re)production of the Islamic woman's visual images in Brazilian photojournalism, with the 
question of genre as the reflexive principle. In more concrete terms, it is queried which women, characterized as being part of the Islamic world, allow themselves to be seen in certain media; what impressions do they evoke in the Brazilian female iconographic context, because of the marks and construction mechanisms that crystallize them as images; and what axiomatic values seem to sustain this regime of Western visibility from something which is eccentric or eastern to it.

The textual definition of East and West is critical for the beginning of this paper. In the Aurélio Buarque de Hollanda dictionary, the word "East" is defined as "1. Relative to the East. 2. Located in the East. 3. That which originates there. 4. That which lives or vegetates in the East. 5. Characteristic of the Eastern countries or their people; peculiar to them", while "West" is defined as "Of, belonging or relative to, or peculiar to the West. 2. Located in the west. 3. That inhabits the areas of the West". From a literal point of view of the dictionary definitions, the blueprint of a binary spatialization organizes the relationship between the two concepts: here/there, and only the term, separated from the expresser, is marked in the text because of the use of the operators of the shifting out in the third person: there/them. Although they are considerations of a semantic nature, they formalize with ample pertinence an opposition which will be subjacent to the analyses carried out of the visual material, which are the pictures. Summing up, how does one characterize the women there, so explicitly different from these here?

In Pierre-Jean Amar's book, Le photojournalisme (2000: 106), the author transcribes a quote of Félix Guattari, which is an example to articulate our position in relation to the press photographs:

Une information resulte d'abord de la sélection et de la délimitation de l'événement. Un événement, par essence, est marqué par des dimensions affectives, traversé par des axes de valeur, toutes choses qui ne peuvent être appréciées que d'un point de vue particulier, singulier. [...] Qu'il y ait du journalisme d'information bien sûr! Mais que les journalistes ne gomment pas, sous couvert d'objectivité, leur singularité ${ }^{3}$.

Likewise, the choice of Islamic women to visually depict the events of the Islamic world, covering themes such as war, elections, popular manifestations and daily activities, is not unfounded and one should not look upon them naively.

The woman enters as a singular way of forging a visualization and sharing not only the cognitive content, but also "the affective dimensions 
and the value axes" of whoever (be it a journalist, photographer, publisher, editor or a team that assumes the editorial perspective of the media) manages the treatment and exposure of information.

Therefore in this study, the intentions of the photographers, publishers or editors are not primary, as are the choice, use and composition of the images in the newspaper pages. In essence it is a study from the standpoint of reception, viewed as possibilities of interpretation highlighted by singular marks left in the journalistic discourse.

In the manner of portrayal of the Islamic women, some recurring mechanisms have been observed, related both to the issue of the link between the image and the verbal text, and to the procedures of photographic protocol employed. Except for the series of articles about the Iranian women's attitude of renewal, initiated by Sérgio Dávila in the Folha De São Paulo on 5/22/2006, all the other articles include photographs of the women as illustrations of a verbal text in which this theme has not been developed. The texts refer first and foremost to the ethnic and religious conflicts and the civil war in the Middle East, as well as to the disagreements with the Western countries, especially the United States, intransigent after the attacks of 9/11/2001, and reiterated with the war against the Taliban regime in Afghanistan, the hunt for Saddam Hussein in Iraq and more recently, the impasse with Iran on the matter of nuclear technology 4 . From the point of view of their photographic configuration, the women are captured in shots, frames and recurring productions, in which the chromatic values of the referent (such as the use of the color black for the mantle, the chador, the hijab and the nikab, for instance) contribute to the image's entirety with surprising effects both esthetically and in symbolic content. This is what this study has attempted to demonstrate.

Because of the blend of the information revealed here - the relationship between Islamism and the topic of reproduction of images, especially of "their wives"; the effects of the induced strangeness, to Western eyes, because of the difference in the donning of garments and cultivation of customs by Eastern women; the reciprocal images, most of which are filtered through socio-cultural clichés, from both sides, mediated mainly by the channels of communication, news agencies and information from every sector of the hegemonic realm of the global village and, finally, the premeditated complexion of the use of photos by the newspapers - we are led to consider the theme because of the one-sidedness of these encroachments, aware of the part that they play in the construction of the 
female image in the world in question, not only by the media but also by theoretical texts, including this one.

The first matter, regarding the injunction against disclosing images in Islamic culture, has a technical consequence for photography: these women are usually portrayed from the side or the back in their daily activities, and from the front, in a close-up, either in conditions of the drama of death, and the display of suffering, allowing an ostensive exchange of looks - which grasps the image and which fixes the dramatic expression on a lens that will allow the extent of its particular pain to be told to the world - or in the shot focused on the eyes, differentiated furtively or face-to-face. In this encounter, the anonymity of such a woman is neutralized in favor of the establishment of a trait common to all human beings: she is also a mother, a sister, a daughter, a wife, a friend, a relative or a neighbor.

From the technical inflection, consequently, esthetic effects are derived. It can be affirmed that on the level of the illustrations represented, they acquire added, rich meanings with the organization of their manners of expression. Based on Félix Thürlemann's concepts, the figurative level was considered "explicans" and the plastic level "explicandum", from which the handling of the women in the media, illustrating political themes, allows one to delve into the cultural evocativeness which such imagery impels, from which an appreciation is derived of the issues and people involved in the different conflicts. A hypothesis was suggested that the Islamic woman's image is configured as a vector of formationreproduction of an imaginary being, decreed in negative notions, in relation to which she appears as the visual operator with a superior argumentative influence.

For an analytical effect at the plastic level, certain types of agents critical to the outline of this hypothesis were distinguished: the chromatic aspect, the topology or composition of the images and the eidetic component, that is to say, the configuration of the shapes. Based upon the idea that the women dressed in black are exhibited, in the images analyzed, as passive figures, readily designated as "Islamic" women, in a plastic perspective, such content is organized in the following manner, resulting in the connotative values of its assessment: the topological and eidetic qualities are configured as elucidative of the "Islamic women" content, or, as Thürlemann affirms (1982: 81), they will then be, at a primary level of immediate assessment, conveyors of meaning, embodying the intervenient role of the color black as an organizing element of the visual and symbolic images generated. 
Without considering it a priori as an absolutely negative color, the evaluative point of view is adopted which makes Kandinski, in the book Du spirituel dans l'art, reproduced in Thürlemann's text (1982: 91), an expression of the imaginary West related to the use of black clothes in situations not distinguished by so-called social taste.

Comme um 'rien' sans possibilités, comme um 'rien ` mort après la mort du soleil, comme um silence éternel, sans avenir, sans l'espérance même d'un avenir, résonne intérieurement le noir. Em musique, ce qui y correspond, c'est la pause qui marque une fin complete, qui será suivie, ensuite, d'autre chose peut-être, - la naissance d'un autre monde. Car tout ce qui est suspendu par ce silence est fini pour toujours: le cercle est fermé. Le noir est comme um bûcher éteint, consumé, qui a cessé de brûler, immobile et insensible comme um cadavre sur qui tout glisse et que rien ne touche plus. II est comme le silence dans lequel entre le corps après la mort quand la vie s'est usée jusqu'au bout ${ }^{5}$.

\section{PLASTIC RESOURCES: CHROMATIC, EIDETIC AND TOPOLOGICAL}

The manner in which the silhouette, outlined by the women dressed in mantles and black veils, is exhibited in the photographs has direct implications for the propinquity of figure-background. Two procedures are common: either the black color of the garments appears to be diluted on the surface of the image, producing, in contrast with clear shapes, a mere backdrop (fig. 1), or the setting in which such feminine illustrations are placed is equally pervaded with a black background.

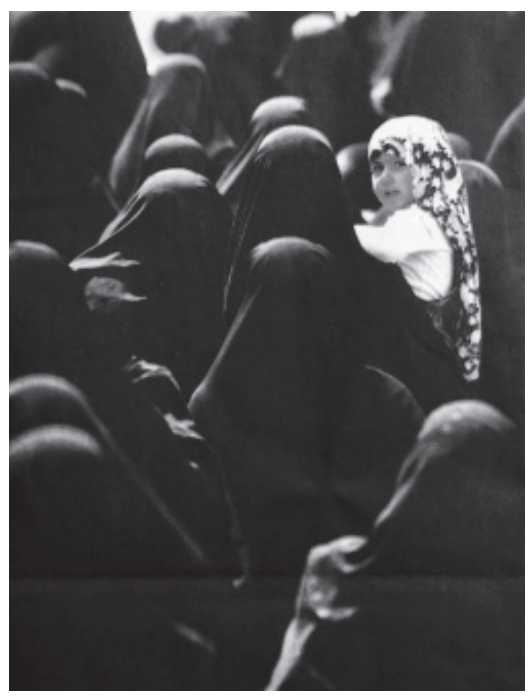

Figure 1 - Folha de São Paulo, 4/30/2006, World Section, article "Petróleo, geopolítica e a guerra com o Irã", subtitle: "Mulheres iranianas vestidas com o chador preto protestam contra o relaxamento no uso da indumentária". Atta Kenare (28 abr. 2006), France Presse. 
In both cases - the exploitation of black in background zones of the image, contriving the context in which such women are framed and embellished, as well as the constitution of the black silhouettes in the backdrop of the manifest surface - the meaning effects are marked by connotative values. The chromatic uniformity, or actually achromatic because of the splash of black, dilutes the figurative contours, which are barely hinted like an anonymous and symmetrical crowd. There is no way to avoid the association with the idea of loss of individualities, obtained owing to the process of deconstruction of the figurativeness being tantamount to the passivity at hand in the group of united women. In these cases, the homogenous background of the black paint influences the eidetic agent, annulling the human forms and rearranging the topology of the image. If, in the referent, the concealment of the physique is accomplished by the shield of the cloth, in photography the process is made homologous by the layout of the women in strategies for general darkening of the image surface.

One variant in the dilution of the contours in the image of the women is in the reconfiguration of the image by the formation of drab or ghastly appearances. These semantic associations are integrated into the referent due to photographic organization devices, as can be observed in Juca Varella's image (2003: 145) in which the moment of the shot registers the action of the wind on the mantle. The bent posture of the woman's body and the attributes acquired by the garments transform her into an image in which one cannot avoid the association of her profile with the image of a crow (fig. 2).

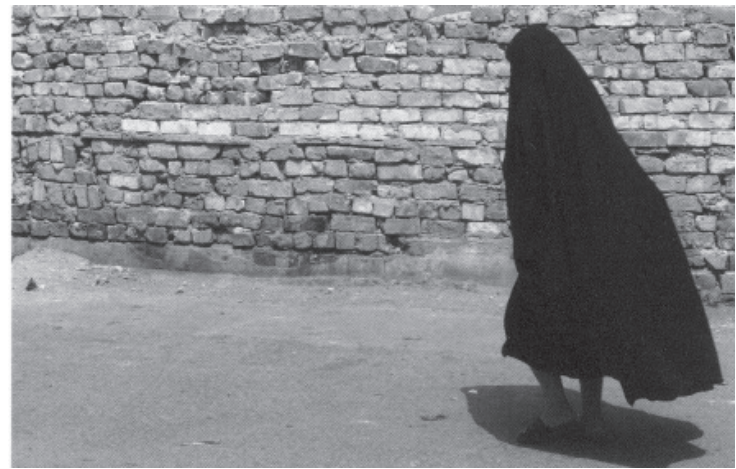

Figure 2 - Diário de Bagdá, 2003, p. 45; title of the section: "Da civilização à barbárie", subtitle: "à direita, mulher passa por muro de pedras no centro de Bagdá". 
In the same way, the photograph of a group of young girls in an amusement park, before a wall painted with the image of the devil, acquires strange effects because of the darkening of the image in contrast with the white of the girls' eyes, which end up fashioning a ghastly visual result with the field (fig. 3).

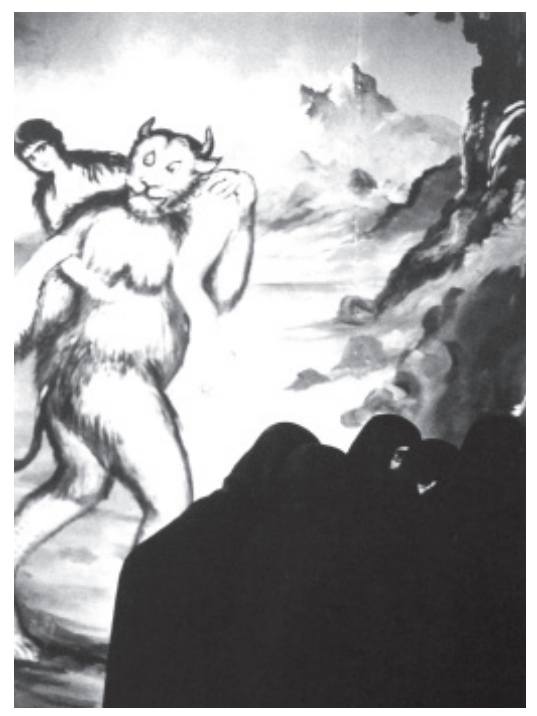

Figure 3 - PERESS, 1997, p. 55, subtitle "Amusement park Teheran", Gilles Peress, France Presse.

Just as the photographic journalist Gilles Peress said, when referring to the period of the Islamic revolution in Iran, a crowd of black-clad women, packed tightly together, peered back like a beast with a thousand eyes (1997: 101).

Intimately related with the predominance of the achromatic is the formal aspect of the fragmentation in the figure portrayed. The three most common mechanisms to process such fragmentation are: the extension of the dark area in opposition to the zones of clarity and light, usually represented with children; the conferring of a geometric form on the body in a clear correspondence to dark abstract forms from other areas of the image (fig. 4); and, particularly concerning the close-up of the eyes, the structure in abyss insinuated by the format of the open void of the veil and the human eye (fig. 5). 
On one hand, such procedures lead one's attention directly to the divided body, to the manifestation of the human by one of its parts, with the eye the strongest of the impressions. There is, however, correspondingly, an excessive valorization of the esthetic character of the image, reiterating the arousal of the mystery that envelops the referent covered in a glimpse of the figure represented. More than a referent, the Islamic female figure is ratified as a photographic object and more than an indication of reality with the object esthetically built. The fragmentation exposes then not only what is not shown, or not said, but what remains to be said beyond the crystallized figures in a style of dressing or exhibition. This tension between exposition and concealment models the woman in a type of mythic dimension defined by the contradictory conditions of her own existence, a fact accentuated by the emphasis on the eyes which are cast on the opening of the hijab, in a clear allusion to the space through which all the expressiveness of speech not consummated reveals itself, like a finger that is shown stained in blue ink after voting.

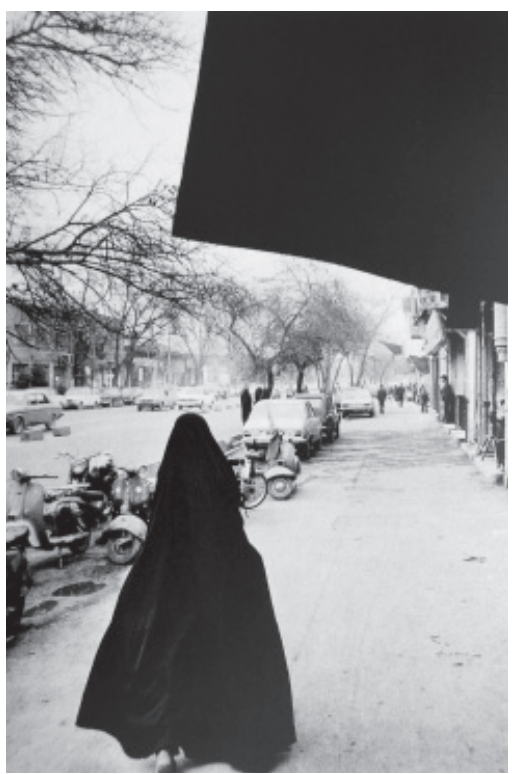

Figure 4 - PERESS, 1997, p. 33, subtitle "Furniture store, Teheran, Gilles Peress, France Presse. 


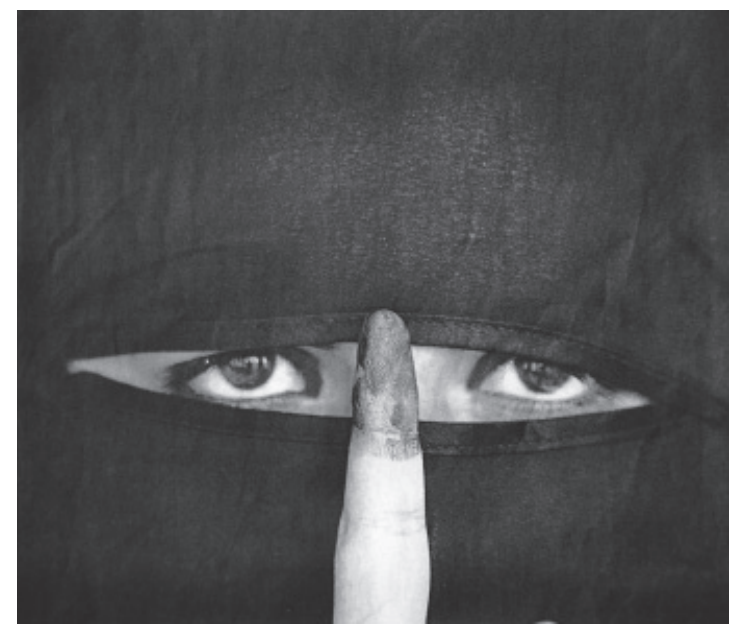

Figure 5 - Folha de São Paulo, 02/04/2006, World Section, A 31, article "Democracia requer paciência", subtitle: "Iraquiana mostra o dedo com tinta após votar na eleição de 2005, etapa crucial da campanha para democratizar o país", Ali Jareki (15 dez. 2005), Reuters.

Another category in the fragmentation of the female figure consists of its modeling in the foreground, expressing the pain of the tragedy that unfolds in the background. The disproportionate shot of the face, either facing upwards as in a state of spiritual evocation or downwards in an attitude of lament, positions the woman as the vector of dramatics in the situations induced by the conflicts and someone for whom nothing else is left other than to suffer and wait (fig. 6).

This photographic strategy is common in diverse cultures, placing the woman (and also frequently the child) as the catalyst of the dramatic force of the event, but it imparts a curious stamp in some of the pictures examined, overlapping the manifestation of pain with the aspectual trait of excess, and in this case, the boundary between the suffering and the "hysterical" woman is thin, creating a certain ambivalence in the manner of interpreting the image. The drab illustrations already referred to contribute strongly to this posture.

The reiteration of children in the series, in which the adult's presence (man or woman, see Fig. 1) appears strongly equable, accentuates the opposition between infantile spontaneity and that impression of a massy subject which the pictures impose, and which obviously favors a particularized interpretation of the societies to which they belong, since the effect that the press renders upon the imagination of the public is widely known ${ }^{6}$. When referring to the spectacle of terrorism, just as 


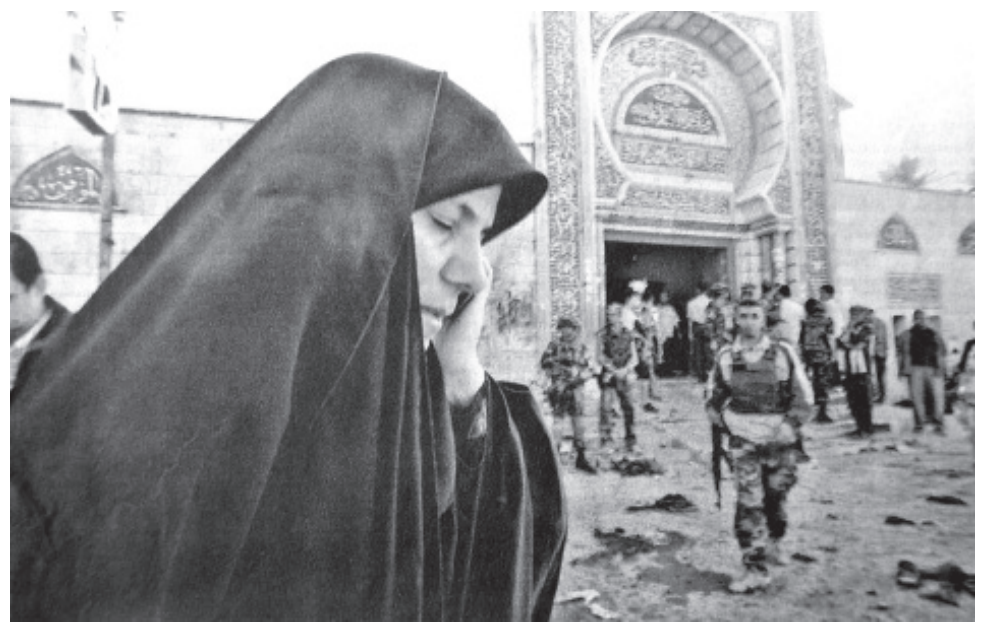

Figure 6 - O Estado de São Paulo, 08/04/2006, front page, article "Bombas matam 79 no Iraque", subtitle: “Dor - Mesquita de Buratha, no norte de Bagdá: matança ocorreu um dia depois de outro atentado na cidade sagrada xiita de Najaf, onde dez pessoas morreram." Khalid Mohammed, Associated Press.

it appears in the media, J. Wainberg affirms that the press is usually "accused of constructing and disseminating epithets that help the people to understand the world based upon certain ideological presuppositions. Among these epithets are countless categories of thought that instigate hostility against the enemy. The war rhetoric describes the opponent as a foreigner, different, strange, heretic and other similar terms that shape the images used in those disputes" (2005: 69-70). The media show begins with the exhibition and confirmation of the stranger without any elaborate contextualizing; it enters as second nature in the reports that expose the violence, conflict and terrorism - not only do the defining elements of those actions that startle us seem to be concentrated on it but also mainly on the potential risk that the other societies represent. This choice, although usually involuntary because the journalist is also a citizen permeated by values, beliefs and prejudices, ends up by dictating a repeated vision, saturated with the other, assimilating it naturally with that which was constructed internally.

\section{Homologizing the plastic dimension with the latent content}

Thus the woman fashioned by those images appears as one whose identity consists exactly of a certain of lack of identity - the traits of the 
"formless" and the "deformed" at the same time defined by the dilution of the figure or by its fragmentation, inevitably induce the connotative content of a world of passivity, concealment and anonymity. However, since the verbal texts do not inform us about the female condition in such cultures, their photos are seen as a mechanism of their disqualification from their social venue and they can be seen either as victims or as extreme illustrations of the high degree of intolerance of a cultural microuniverse.

It is necessary, however, to make it clear that such a profile of the female character is only available for examination by cultures in which the exhibition of the body in all its details, not only by procedures of denudation but also by insinuations of what is obscured, has assumed such a natural character that everything that speaks against it gives the impression of a manifestation of absurdity. Therefore any discussion regarding "freedom" of physical expression and of the codes of fashion, must be accomplished in established historical and socio-cultural conditions because the acts of concealing or exhibiting oneself really constitute equally entrenched behavior, mainly under the authority of the supposedly hegemonic male taste.

For the purposes of this study, the fact that such images circulate in Brazilian newspapers in posted conditions that add informatively to the verbal text, is of the author's concern, while they exhibit referents covered with mantles and black veils blended into the dark background or constituted in background scenes, hardly scrutinized by the investigative and curious attention of the reader. In this context, the woman appears as the weakest element of an extremely rigid structure under male dominance, appearing as a metonymical figure, representing strangeness and obscurity. Seen in this manner, she sanctions the creation of a political discussion about the premise of a clash of civilizations in which the other side appears as the archetype of the different, the unacceptable and the unyielding. As the representative of a society which one wants to repudiate, the woman is not approached directly in her particular condition but as a vector of the suffering imposed upon her by a structure in which she outlines the most intense manifestation of its dramatic aspect. 


\section{NOTES}

1 An oral presentation of this article was made at the Seminário Internacional Fazendo Gênero 7, in the Federal University of Santa Catarina (UFSC), Florianópolis, Brazil, in August 2006.

2 In research published by Folha de São Paulo on June 23rd, 2006 (Caderno Mundo, p. A13), undertaken in 15 countries by the American research institute, Pew, Muslims consider Western countries, especially the USA and the EU, selfish, immoral and avaricious while the Western countries perceive Muslims as arrogant, violent and intolerant.

3 One bit of information is the result, from the start, of selection and adumbration of the occurrence. An occurrence, in essence, is identified by affective dimensions, permeated by value axes, objects which can only be appreciated from a particular, singular point of view. [...] Of course there exists informational journalism! But journalists must not eradicate, under the guise of objectivity, their uniqueness.

4 After the preparation of this study, the media has been barraged with photographs of women from Lebanon, and especially of dead Lebanese children by virtue of attacks by Israeli soldiers. Here the emphasis is on stronger images, associated with shocking images, which serve as a dramatic vector of public attention to the bloody nature of this war. Therefore there has been a change in the sociopolitical situation, which beforehand was configured in a context in which the conflicts existed in a still latent state.

5 Like a "nothing" without possibilities, like a "nothing" dead after the death of the sun, like an eternal silence, without a future, without even the hope of a future, chanting black internally. In music, what complements it, is the pause which marks a complete end, and which will be followed by something else perhaps, - the birth of another world. Because everything which is suspended by this silence is finished forever: the circle is closed. Black is like a blown-out candle, consumed and which stopped shining, motionless and insensitive as a corpse on which everything slides but nothing touches. It is like the silence of the body after death when life has been consumed to the end.

6 V. CAETANO, K. \& FISCHER, S. O véu, a bruma, a tela e a face - o negativo do documental na fotografia de jornalismo. Work presented at the XV Encontro Anual da Associação Nacional dos Programas de PósGraduação em Comunicação, Bauru, SP: Programa de Pós-Graduação em Comunicação, FAAC-UNESP, June 7, 2006. 


\section{BIBLIOGRAPHY}

BAKHITIN, AMAR, Pierre-Jean. Le photojournalisme. Paris: Nathan Université, 2000.

BAXANDALL, M. Padrões de intenção: a explicação histórica dos quadros. São Paulo: Companhia das Letras, 2006.

DÁVILA, Sérgio. Diário de Bagdá: a guerra do Iraque segundo os bombardeados. São Paulo: DBA Artes Gráficas, 2003.

DUBOIS, Philippe. O ato fotográfico e outros ensaios. Campinas: Papirus, 1994.

GILLES PERESS. Telex Iran: in the name of revolution. Zurich/Berlin/New York: Scalo, 1997.

FERREIRA Jr., J. Capas de jornal: a primeira página e o espaço visual. São Paulo: Senac, 2002.

FLOCH, J.-M. Les formes de l'empreinte: Brandt, Cartier-Bresson, Doisneau, Stieglitz, Strand. Périgueux, Pierre Fanlac, 1986. . Identités visuelles. Paris: PUF, 1995.

FONTANILLE, J. Significação e visualidade: exercícios práticos. Porto Alegre: Sulina, 2005.

GREIMAS, A.-J. De l'imperfection. Périgueux: Pierre Fanlac, 1987.

GUIMARÃES, L. As cores na mídia: a organização da cor-informação no jornalismo. São Paulo: Annablume, 2003.

KOSSOY, Boris. Realidades e ficções na trama fotográfica. Cotia, SP: Ateliê Editorial, 2000.

KRAUSS, R. El inconsciente óptico. Madrid: Tecnos, 1997.

LANDOWSKI, E. O olhar comprometido. In: Galáxia: Revista Transdisciplinar de comunicação, semiótica, cultura. EDUC, n² 2, 2001 p. 19 - 56.

PEREIRA, L. H. M. M. Fotografia, a poética do banal. Brasília: Ed. UnB; São Paulo: Imprensa Oficial do Estado, 2000.

SASSON, J. P. Princesa: a história real da vida das mulheres árabes por trás de seus negros véus. Rio de Janeiro: Best Seller, 2005.

SCHUON, FRITHJOF. Para compreender o Islã: originalidade e universalidade da religião. RJ: Nova Era, 2006.

SEIERSTAD, Asne. O livreiro de Cabul. Rio de Janeiro: Record, 2006.

SOUSA, J. P. Fotojornalismo: introdução à história, às técnicas e à linguagem da fotografia na imprensa. Florianópolis, SC: Letras Contemporâneas, 2004.

THÜRLEMANN, F. Paul Klee: analyse sémiotique de trois peintures. Lausanne/Suisse: L'Age d'Homme, 1982. 
TOWELL, Larry. Then palestine. NY: Aperture, 1998.

WAINBERG, J. A. Mídia e terror: comunicação e violência política. SP: Paulus, 2005.

ZANCHETTA Jr., Juvenal. Imprensa escrita e telejornal. São Paulo: Ed.da UNESP, 2004.

Kati E. Caetano is Professor in the Master's Program of Communication and Languages, Tuiuti University of Paraná, Curitiba, PHD in Letters from USP, Post-Doctoral Studies in Semiotics in France. Coordinator of the Research Group in Photography in the Media/UTP/ PR/Brazil.

E-mail: katicaetano@hotmail.com 